Article

\title{
Comparative Study of the Bioactive Properties and Elemental Composition of Red Clover (Trifolium pratense) and Alfalfa (Medicago sativa) Sprouts during Germination
}

\author{
Elena Roxana Chiriac ${ }^{1,2}$, Carmen Lidia Chiţescu ${ }^{2, *}$, Claudia Sandru ${ }^{3}$, \\ Elisabeta-Irina Geană ${ }^{3,4}\left(\mathbb{D}\right.$, Mariana Lupoae ${ }^{2, *}$, Michaela Dobre ${ }^{2}$, Daniela Borda ${ }^{5}$ (D), \\ Cerasela Elena Gird ${ }^{1}$ and Rica Boscencu ${ }^{1}$ \\ 1 Faculty of Pharmacy, "Carol Davila” University of Medicine and Pharmacy of Bucharest, \\ 37 Dionisie Lupu Street, Sector 2, 020021 Bucharest, Romania; roxana.elena.chiriac@gmail.com (E.R.C.); \\ cerasela.gird@umfcd.ro (C.E.G.); rica.boscencu@umfcd.ro (R.B.) \\ 2 Faculty of Medicine and Pharmacy, “Dunarea de Jos” University of Galaţi, 35 A.I. Cuza Str., 800010 Galaţi, \\ Romania; michaela.dobre@ugal.ro \\ 3 National Research \& Development Institute for Cryogenics and Isotopic Technologies (ICSI Rm. Valcea), \\ 4th Uzinei Street, 240050 Râmnicu Vâlcea, Romania; claudia.sandru@icsi.ro (C.S.); \\ irina.geana@icsi.ro (E.-I.G.) \\ 4 Faculty of Applied Chemistry and Materials Science, Politehnica University of Bucharest, 1-7 Polizu Str., \\ 011061 Bucharest, Romania \\ 5 Faculty of Food Science and Engineering, “Dunarea de Jos” University of Galaţi, Str. Domnească 111, \\ 800201 Galaţi, Romania; daniela.borda@ugal.ro \\ * Correspondence: carmen.chitescu@ugal.ro (C.L.C.); mariana.lupoae@ugal.ro (M.L.)
}

Received: 4 September 2020; Accepted: 13 October 2020; Published: 16 October 2020

check for updates

\begin{abstract}
Considering the growing interest in functional foods, the identification of the individual species of elements is of great importance in understanding specific nutraceutical properties. The present study aims to compare the dynamic of the elemental content $(\mathrm{K}, \mathrm{Na}, \mathrm{Ca}, \mathrm{Mg}, \mathrm{Fe}, \mathrm{Cu}$, $\mathrm{Zn}, \mathrm{Mn}, \mathrm{Ni}$, and Se), total polyphenols, and antioxidant activity of Trifolium pratense L. and Medicago sativa L. sprouts in different germination stages. The elemental profile was established by atomic absorption spectroscopy after the microwave acid digestion of the samples, while total polyphenols and anti-radical activity were evaluated by UV-Vis spectroscopic methods. Phenolic compounds and anti-radical activity of both alfalfa and red clover sprouts varied with germination stages. Germination can significantly increase the anti-radical activity in the first 3 days of germination, followed by a decline in the following days. An increase in total polyphenols was noticed, starting from the second day of germination in both plant species. There were significant $(p<0.05)$ differences for $\mathrm{Ca}, \mathrm{Na}, \mathrm{Fe}, \mathrm{K}, \mathrm{Zn}$, and $\mathrm{Mg}$ contents among the sprouts, depending on the germination stage and plant species. The calcium contents of alfalfa ranged between $200.74 \mu \mathrm{g} / \mathrm{g}$ DW (raw seeds) and $2765.31 \mu \mathrm{g} / \mathrm{g}$ DW (sprouted), while in red clover between $250.83 \mu \mathrm{g} / \mathrm{g}$ DW and $601.59 \mu \mathrm{g} / \mathrm{g} \mathrm{DW}$. Maximum selenium content in alfalfa sprouts, reached in the $3 \mathrm{rd}$ day of germination $(11.42 \mu \mathrm{g} / \mathrm{g}$ $\mathrm{DW})$, exceeded the maximum value measured in red clover $(9.42 \mu \mathrm{g} / \mathrm{g}$ DW). The data were subject to statistical processing using analysis of variance (ANOVA), multivariate analysis (PCA) and hierarchical clustering analysis (HCA).
\end{abstract}

Keywords: trace-elements; atomic absorption spectroscopy; antioxidant activity; isoflavones; nutraceuticals 


\section{Introduction}

Trifolium pratense (red clover) and Medicago sativa (alfalfa) are considered as potential natural sources of bioactive compounds with beneficial effects in the prevention and treatment of many diseases, which is demonstrated by various scientific studies [1-4]. Major bioactive compounds in the aerial parts of both plant species are isoflavonoids with estrogenic activities, flavonoids, phenolic acids, fatty acids, sterols, and saponins in alfalfa [3,5]. Red clover has been used for the protection of the cardiovascular system, improvement of bone health, and beneficial effects in breast, ovarian, and prostate cancers $[2,6]$ and it is recognized as a remedy for menopausal disorders [1,7]. The extract of alfalfa aerial parts showed a moderate anti-inflammatory effect $[3,8]$, therapeutic potential in the treatment of hypercholesterolemia [9], and in relieving disorders of the central nervous system [10].

Edible seeds and sprouts of plants from the Fabaceae family have been consumed since ancient times in Asia [11]. Sprout consumption has recently become a worldwide trend, as they are considered a functional food due to the bioactive compounds content $[12,13]$. As a result of the increased activities of hydrolytic enzymes, sprouting leads to improvements in the contents of total proteins, lipids, several essential amino acids, simple sugars, and B-group vitamins [14]. Along with bioactive polyphenols content, sprouts are a particularly rich source of minerals [12,15]. Moreover, in vitro studies showed enhanced bioavailability of zinc, iron, and calcium during sprouting [16].

Among the phytonutrients represented by polyphenols, phytoestrogens, and antioxidants, sprouts can also supply a range of macro- and micro-elements to humans [15]. The trace elements have a fundamental role in the control of oxidative reactions and antioxidant/free radical balance in biological tissues. For example, manganese (Mn) is a component of Mn-SOD enzyme protecting mitochondria from toxic effects of free radicals [17], copper $(\mathrm{Cu})$ is a component of cytochrome oxidase and zinc-superoxide dismutase ( $\mathrm{Cu}, \mathrm{Zn}-\mathrm{SOD})$ enzymes, which play an important role as $\mathrm{O} 2 \bullet^{-}$ scavengers [17,18]; zinc ( $\mathrm{Zn})$ is an SOD component as well and is essential in the maintenance of vascular endothelial integrity and in the immunological system properly functioning [18], selenium (Se) is a structural part of several forms of glutatione peroxidase, an enzyme responsible for the removing of peroxides and $\mathrm{H}_{2} \mathrm{O}_{2}$ with major roles in antioxidant defense, regulation of redox state of several molecules, and regulation of thyroid hormone action [17].

Nutritional intake of selenium has been suggested to protect against postmenopausal ovarian cancer [19]. Studies revealed the importance of zinc in depressive symptoms, as well as of iron in aspects such as mood and cognition in premenopausal women [20]. A possible relation between the low levels of $\mathrm{Zn}, \mathrm{Fe}$, and $\mathrm{Mg}$ and the occurrence of depressive symptoms in postmenopausal women was suggested in a recent trial study [21].

The aim of the present study was to evaluate the polyphenolic bioactive properties and the elemental composition of Trifolium pratense L. and Medicago sativa L. sprouts as a potential source of dietary supplements. Recent studies have demonstrated that high concentrations of isoflavones with estrogenic activity and flavonoids in red clover (RCV) and alfalfa (ALF) sprouts support their use in human nutrition as nutraceuticals [11,22,23]. However, the elemental composition of RCV and ALF sprouts received little attention. One study [15] reported the quantification of eight minerals, including $\mathrm{Mg}, \mathrm{Na}, \mathrm{Ca}, \mathrm{K}, \mathrm{Fe}$, and $\mathrm{Zn}$ in seeds and 5-day germinated sprout of ALF. Regarding minerals in RCV sprouts, we found one study reporting the quantification of five minerals (Ca, $\mathrm{K}, \mathrm{Mg}$, $\mathrm{Fe}$, and $\mathrm{Zn}$ ) and $P$ in 5-day germinated sprouts [24] The influence of germination in mineral content was evaluated in other edible sprouts as: different beans species [25] and flax seeds [26]. Therefore, our study fills in a gap of the current research on this particular topic, performing a comprehensive elemental profile of RCV and ALF seeds and sprouts during a 5-day germination process. Twelve elements, including Ca, $\mathrm{Mg}, \mathrm{K}, \mathrm{Na}, \mathrm{Zn}, \mathrm{Fe}, \mathrm{Se}, \mathrm{Ag}, \mathrm{Ba}, \mathrm{Ni}, \mathrm{Cu}$, and $\mathrm{Mn}$, were quantified by atomic absorption spectroscopy (AAS) after the microwave acid digestion of the vegetal samples.

Possible correlations between the obtained data are also in the scope of this study.

Little is known on changes in minerals, total phenolic content, and anti-radical activity in relation to the days of germination in Trifolium pratense and Medicago sativa sprouts. To our knowledge, 
there are no published studies regarding the monitoring of the dynamic of the elemental profile during germination nor in RCV neither in ALF sprouts.

\section{Results and Discussions}

\subsection{Total Polyphenols and Anti-Radical Activity}

The total polyphenols (TP) in T. pratense and M. sativa seeds and sprouts extracts was determined by the Folin-Ciocâlteu spectrophotometric method and the anti-radical activity (AA) has been evaluated by $\mathrm{DPPH} \bullet$ free radical scavenging assay. All experiments were done in duplicates. As observed in Figure 1, a decrease in TP was noticed during the first 2 days of germination in both plant species. On the other hand, all the assessed extracts were able to reduce the radical DPPH $\bullet$. The raw data are presented in the supplementary file (Table S1).
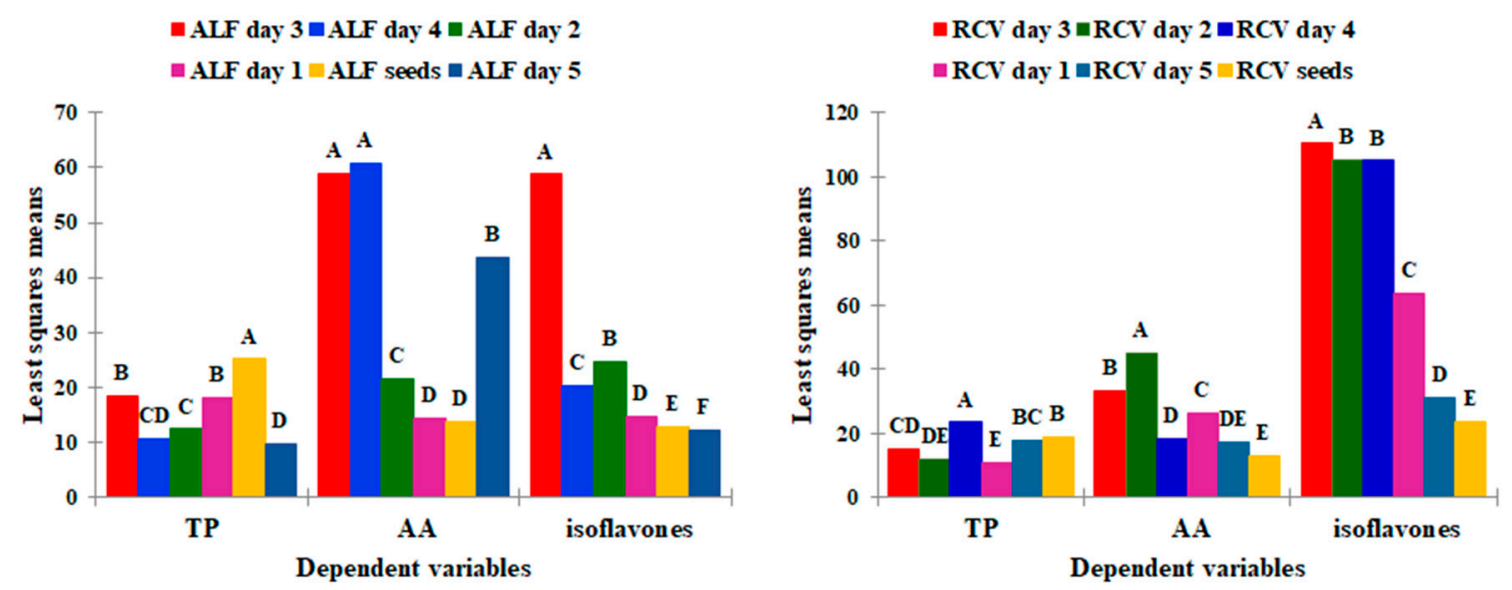

Figure 1. Variation of the total phenolic (TP) content (mg gallic acid eq/g DW), the anti-radical activity (AA) as scavenging capacity of DPPH• (\%) and isoflavones content $(\mu \mathrm{g} / \mathrm{g} \mathrm{DW})$ in ALF and RCV sprouts during germination (sprouts samples was coded as: day 1-first day of germination; day 2-second day of germination; day 3 - third day of germination; day 4-fourth day of germination; day 5-fifth day of germination). Different uppercase letters corresponding to the bars denote significant differences according to Duncan test $p \leq 0.05$.

ALF sprouts extracts exhibited an increased anti-radical activity with the on-going germination (Figure 1). AA in the fourth day of germination increase 4.37-fold compared to the activity in seeds, while in the fifth day, a decrease was registered compared with day 4 . A nonlinear correlation was observed between the dynamics of the total phenols and anti-radical activity in ALF sprouts with a maximum of TP in the third day of germination (18.51 mg gallic acid eq/g DW).

In contrast, in the RCV sprouts' extracts the activity against DPPH• was negatively correlated with the total phenolic amount (Figure 1), probable due to the changes in polyphenols profile associated highly with anti-radical activity. The highest TP was observed in the fourth day of germination while the AA decreased from a maximum reached in the second day of germination. However, even if the TP in ALF seeds was higher than in RCV seeds (25.14 compared to $18.74 \mathrm{mg}$ gallic acid eq/g DW), during germination, the total polyphenols in RCV sprouts exceeded ALF sprouts in the fourth day (23.34 compared to $10.62 \mathrm{mg}$ gallic acid eq/g DW).

Our results are consistent with the total polyphenols and antioxidant/anti-radical activity in kinetic investigations on germinated cereals or vegetable seeds $[27,28]$, Thus, similar with other study on M. sativa [27] showing close TP and AA values and the same trends as observed in our results, TP of ALF sprouts decreased over a 2-day period and increased over the next 2 days while the variation of the AA in ALF indicates an increase during the first 4 days of germination followed by a decline in the next day. As with other authors reporting results on germinated cereals [28], in our study for both 
plant species, the lowest TP was found in day 1 and day 2 during the germination process, followed by an increase during the following days.

Selected isoflavones with estrogenic activity (genistin, genistein, daidzin, daidzein, formononetin, glycitein, and myricetin) were quantified by Chiriac, [23] in a previous work by high resolution mass spectrometry (Table S1, Supplementary Materials). In order to highlight significant differences among the samples of ALF and RCV sprouts extracts, the resulted biochemical data were statistically processed by analysis of variance (ANOVA). Thus, according to the Duncan's test, different uppercase letters corresponding to the bars indicated significant differences $(p<0.05)$ between the corresponding RCV and ALF samples (Figure 1).

The ANOVA results indicate that TP, AA, and total isoflavones content were significantly different depending on the day of germination for ALF and RCV sprouts. It is worth noting that the AA and isoflavones contents corresponding to the third and fourth days of germination in ALF and RCV sprouts were significantly higher compared to the other days of germination.

The correlation analysis (Tables S2 and S3) shows low to moderate correlations between the parameters. Correlation coefficients with values higher than 0.5 were used for the interpretation of correlation analysis. For both, ALF and RCV sprouts, negative moderate correlations were obtained for TP with AA, while positive moderate correlations were obtained for AA with isoflavones content. Low correlations were observed for TF with isoflavones.

\subsection{Elemental Profile Composition}

A total of 12 elements $(\mathrm{Ca}, \mathrm{K}, \mathrm{Mg}$, $\mathrm{Na}, \mathrm{Zn}, \mathrm{Fe}, \mathrm{Se}, \mathrm{Ag}$, $\mathrm{Ba}, \mathrm{Ni}, \mathrm{Mn}$, and $\mathrm{Cu}$ ) were monitored by AAS determination in samples of ALF and RCV seeds and sprouts during the 5-day germination process. The determination of macro- and trace elements in ALF and RCV seeds and sprouts is reported in Tables 1 and 2, as mean and standard deviation of two independent replicates.

Elemental data were examined according to the day of germination of ALF and RCV sprouts using one-way ANOVA. The averages in the same row followed by the same lowercase letter were not significantly different according to the Duncan's multiple range test at $p \leq 0.05$. The ANOVA results showed that the content of $\mathrm{Ca}, \mathrm{Mg}, \mathrm{Na}, \mathrm{K}, \mathrm{Fe}, \mathrm{Zn}, \mathrm{Ni}$, and Mn were significantly different $(p<0.05)$ depending on the day of germination for both ALF and RCV sprouts, while the content of $\mathrm{Cu}$ and Se were not significantly different $(p>0.05)$ during germination.

In the studied samples, $\mathrm{K}$ was the most abundant element, followed by elements like $\mathrm{Na}, \mathrm{Mg}, \mathrm{Ca}$, $\mathrm{Fe}$, and $\mathrm{Zn}$. Ba and Ag weren't found in the analyzed samples.

The amounts of $\mathrm{Mg}$ and $\mathrm{K}$ measured in ALF sprouts was comparable with RCV sprouts, whereas the $\mathrm{Ca}$ and $\mathrm{Na}$ amounts were higher, reaching a level about 4.6-fold higher in ALF sprouts than in RCV for $\mathrm{Ca}$, and 1.56-fold higher for $\mathrm{Na}$, respectively. A 3.5-fold higher concentration of Fe in ALF sprouts than in RCV sprouts was measured in the third day of germination, and also a higher amount of $\mathrm{Zn}, \mathrm{Mn}, \mathrm{Ni}$, and Se. The sum of the elements in ALF exceeded the RCV from the first day of germination, with the same trend maintained throughout the germination process.

Regarding the dynamic of the elemental profile, almost symmetrical patterns were observed during germination for most of the measured elements, shown as relative change in quantity per day compared with raw seeds (Figure 2 and Supplementary Figure S1). While the amount of Zn, Cu, Se, and $\mathrm{Ni}$ trace elements slowly increased during the 5 days of germination, substantial increases were observed for $\mathrm{Ca}, \mathrm{Mg}$, $\mathrm{Na}$, and $\mathrm{K}$ macro-elements. The total amount of minerals in $\mathrm{RCV}$ seeds was above the value in the ALF seeds; however, the increase in the total values was notably higher in ALF.

Although the sum of the measured elements exhibited the same trend, in particular a significant increase starting from the second day of germination, differences between the plants species were observed with respect to the dynamics of some elements (Figure 3). 
Table 1. Minerals in ALF sprouts in $\mu \mathrm{g} / \mathrm{g}$ DW (dried weight) of vegetal material (ALF sprouts samples were coded as: day 1—first day of germination; day 2—second day of germination; day 3 - third day of germination; day 4-fourth day of germination; day 5—fifth day of germination).

\begin{tabular}{|c|c|c|c|c|c|c|}
\hline$\mu g / g$ DW & ALF Seeds & ALF Day 1 & ALF Day 2 & ALF Day 3 & ALF Day 4 & ALF Day 5 \\
\hline $\mathrm{Ca}$ & $200.74^{\mathrm{f}} \pm 7.4$ & $407.02^{\mathrm{e}} \pm 2.9$ & $1269.57^{\mathrm{d}} \pm 2.5$ & $1380.49^{c} \pm 3.1$ & $2018.75^{b} \pm 3.8$ & $2765.31^{\mathrm{a}} \pm 1.4$ \\
\hline $\mathrm{Mg}$ & $2117.59^{\mathrm{e}} \pm 5.6$ & $2299.04^{\mathrm{d}} \pm 5.4$ & $2564.13^{c} \pm 7.7$ & $2720.73^{b} \pm 5.3$ & $2925^{a} \pm 8.1$ & $2933.72^{a} \pm 9.7$ \\
\hline $\mathrm{Na}$ & $818.15^{\mathrm{f}} \pm 3.9$ & $2936.96^{\mathrm{e}} \pm 7.8$ & $2979.59^{\mathrm{d}} \pm 5.5$ & $3231.73^{c} \pm 9.5$ & $3424.39^{b} \pm 8.5$ & $4080^{a} \pm 10.6$ \\
\hline K & $7304.81^{f} \pm 9.4$ & $9428.26^{\mathrm{e}} \pm 4.1$ & $9611.11^{d} \pm 9.6$ & $14,510.2^{\mathrm{c}} \pm 6.2$ & $15,780.49^{b} \pm 8.0$ & $16,475^{\mathrm{a}} \pm 8.9$ \\
\hline $\mathrm{Fe}$ & $131.11^{\mathrm{e}} \pm 1.5$ & $322.79^{b} \pm 4.6$ & $365^{\mathrm{a}} \pm 4.9$ & $236.71^{d} \pm 3.7$ & $257.25^{\mathrm{c}} \pm 4.4$ & $86.2^{\mathrm{f}} \pm 4.6$ \\
\hline $\mathrm{Zn}$ & $57.06^{\mathrm{c}} \pm 2.1$ & $60.37^{b c} \pm 2.3$ & $66.76^{\mathrm{a}} \pm 3.4$ & $64.35^{a b} \pm 2.6$ & $68.25^{\mathrm{a}} \pm 05$ & $68.24^{\mathrm{a}} \pm 1.5$ \\
\hline $\mathrm{Cu}$ & $16.41^{\mathrm{a}} \pm 0.6$ & $17.06^{\mathrm{a}} \pm 0.7$ & $18.12^{\mathrm{a}} \pm 2.6$ & $19.07^{\mathrm{a}} \pm 0.5$ & $18.86^{\mathrm{a}} \pm 2.3$ & $20.12^{\mathrm{a}} \pm 2.3$ \\
\hline $\mathrm{Se}$ & $6.99^{b} \pm 1.3$ & $7.59^{a b} \pm 0.8$ & $7.12^{b} \pm 0.4$ & $11.42^{\mathrm{a}} \pm 1.8$ & $10.41^{\mathrm{ab}} \pm 2.0$ & $7.85^{a b} \pm 2.1$ \\
\hline $\mathrm{Ni}$ & $3.47^{\mathrm{c}} \pm 0.2$ & $3.72^{b c} \pm 0.02$ & $4.12^{a b c} \pm 0.05$ & $3.45^{\mathrm{c}} \pm 0.5$ & $4.84^{\mathrm{a}} \pm 0.2$ & $4.37^{\mathrm{ab}} \pm 0.2$ \\
\hline $\mathrm{Mn}$ & $11.69^{\mathrm{d}} \pm 0.2$ & $12.32^{\mathrm{cd}} \pm 0.7$ & $13.27^{b c} \pm 0.6$ & $11.67^{\mathrm{d}} \pm 0.2$ & $14.09^{b} \pm 0.4$ & $17.99^{\mathrm{a}} \pm 1.0$ \\
\hline$\Sigma$ & $10,668.02 \pm 5.8$ & $15,495.13 \pm 3.1$ & $16,898.79 \pm 6.5$ & $22,189.82 \pm 3.3$ & $24,522.33 \pm 10.4$ & $26,458.8 \pm 4.2$ \\
\hline
\end{tabular}

The values represent the mean of the results obtained for the two replicate analyses \pm standard deviation. Different lowercase letters in the row denote significant differences according to Duncan test $p \leq 0.05$.

Table 2. Minerals in RCV sprouts in $\mu \mathrm{g} / \mathrm{g}$ DW (dried weight) of vegetal material (RCV sprouts samples were coded as: day 1—first day of germination; day 2—second day of germination; day 3-third day of germination; day 4-fourth day of germination; day 5-fifth day of germination).

\begin{tabular}{|c|c|c|c|c|c|c|}
\hline$\mu g / g ~ D W$ & RCV Seeds & RCV Day 1 & RCV Day 2 & RCV Day 3 & RCV Day 4 & RCV Day 5 \\
\hline $\mathrm{Ca}$ & $250.83^{f} \pm 6.9$ & $495.65^{\mathrm{e}} \pm 4.7$ & $539.39^{d} \pm 7.02$ & $563.23^{c} \pm 7.02$ & $589.39^{b} \pm 6.7$ & $601.59^{a} \pm 5.6$ \\
\hline $\mathrm{Mg}$ & $2512.96^{\mathrm{e}} \pm 5.8$ & $2976.09^{d} \pm 3.8$ & $2945.92^{c} \pm 10.3$ & $2928^{b} .13 \pm 9.4$ & $3151.22^{a} \pm 7.1$ & $3347.56^{a} \pm 2.7$ \\
\hline $\mathrm{Na}$ & $223.61^{\mathrm{f}} \pm 4.2$ & $381.09^{\mathrm{e}} \pm 4.5$ & $393.67^{d} \pm 5.7$ & $470.63^{c} \pm 6.6$ & $1166.1^{b} \pm 8.3$ & $2603.66^{\mathrm{a}} \pm 9.9$ \\
\hline $\mathrm{K}$ & $8186.36^{\mathrm{f}} \pm 7.2$ & $8159.3^{\mathrm{e}} \pm 9.4$ & $8202.04^{\mathrm{d}} \pm 3.2$ & $11,760.42^{c} \pm 2.5$ & $15,743.9^{b} \pm 6.2$ & $16,963 \cdot 41^{\mathrm{a}} \pm 7 \cdot 6$ \\
\hline $\mathrm{Fe}$ & $50.61^{\mathrm{e}} \pm 3.2$ & $59.61^{b} \pm 6.6$ & $60.07^{a} \pm 2.6$ & $68.82^{\mathrm{d}} \pm 1.4$ & $114.15^{\mathrm{c}} \pm 3.1$ & $114.68^{\mathrm{f}} \pm 3.0$ \\
\hline $\mathrm{Zn}$ & $39.94^{c} \pm 3.3$ & $48.42^{b c} \pm 1.2$ & $48.8^{a} \pm 0.9$ & $49.13^{a b} \pm 2.1$ & $53.7^{\mathrm{a}} \pm 2.5$ & $49.5^{\mathrm{a}} \pm 1.2$ \\
\hline $\mathrm{Cu}$ & $16.04^{\mathrm{a}} \pm 1.1$ & $17.02^{\mathrm{a}} \pm 1.9$ & $17.64^{\mathrm{a}} \pm 0.9$ & $18.23^{a} \pm 1.5$ & $20.74^{\mathrm{a}} \pm 1.7$ & $19.96^{\mathrm{a}} \pm 3.2$ \\
\hline $\mathrm{Se}$ & $6.16^{b} \pm 1.4$ & $5.67^{b} \pm 1.7$ & $5.85^{\mathrm{b}} \pm 1.2$ & $7.38^{a} \pm 0.8$ & $9.42^{a b} \pm 2.0$ & $8.76^{a b} \pm 0.6$ \\
\hline $\mathrm{Ni}$ & $2.5^{\mathrm{c}} \pm 0.5$ & $2.38^{b c} \pm 0.3$ & $2.64^{a b c} \pm 0.5$ & $2.74^{\mathrm{c}} \pm 0.4$ & $3.47^{\mathrm{a}} \pm 0.4$ & $3.39^{a b} \pm 0.2$ \\
\hline $\mathrm{Mn}$ & $7.87^{\mathrm{d}} \pm 0.5$ & $8.02^{\mathrm{cd}} \pm 0.5$ & $8.09^{b c} \pm 0.7$ & $8.19^{d} \pm 0.3$ & $9.08^{b} \pm 0.6$ & $8.95^{a} \pm 0.8$ \\
\hline$\Sigma$ & $11,296.88 \pm 3.9$ & $12,153.25 \pm 2.4$ & $12,224.11 \pm 2.6$ & $15,876.9 \pm 1.4$ & $20,861.17 \pm 8.9$ & $23,721.46 \pm 3.5$ \\
\hline
\end{tabular}

The values represent the mean of the results obtained for the two replicate analyses \pm standard deviation. Different lowercase letters in the row denote significant differences according to Duncan test $p \leq 0.05$. 

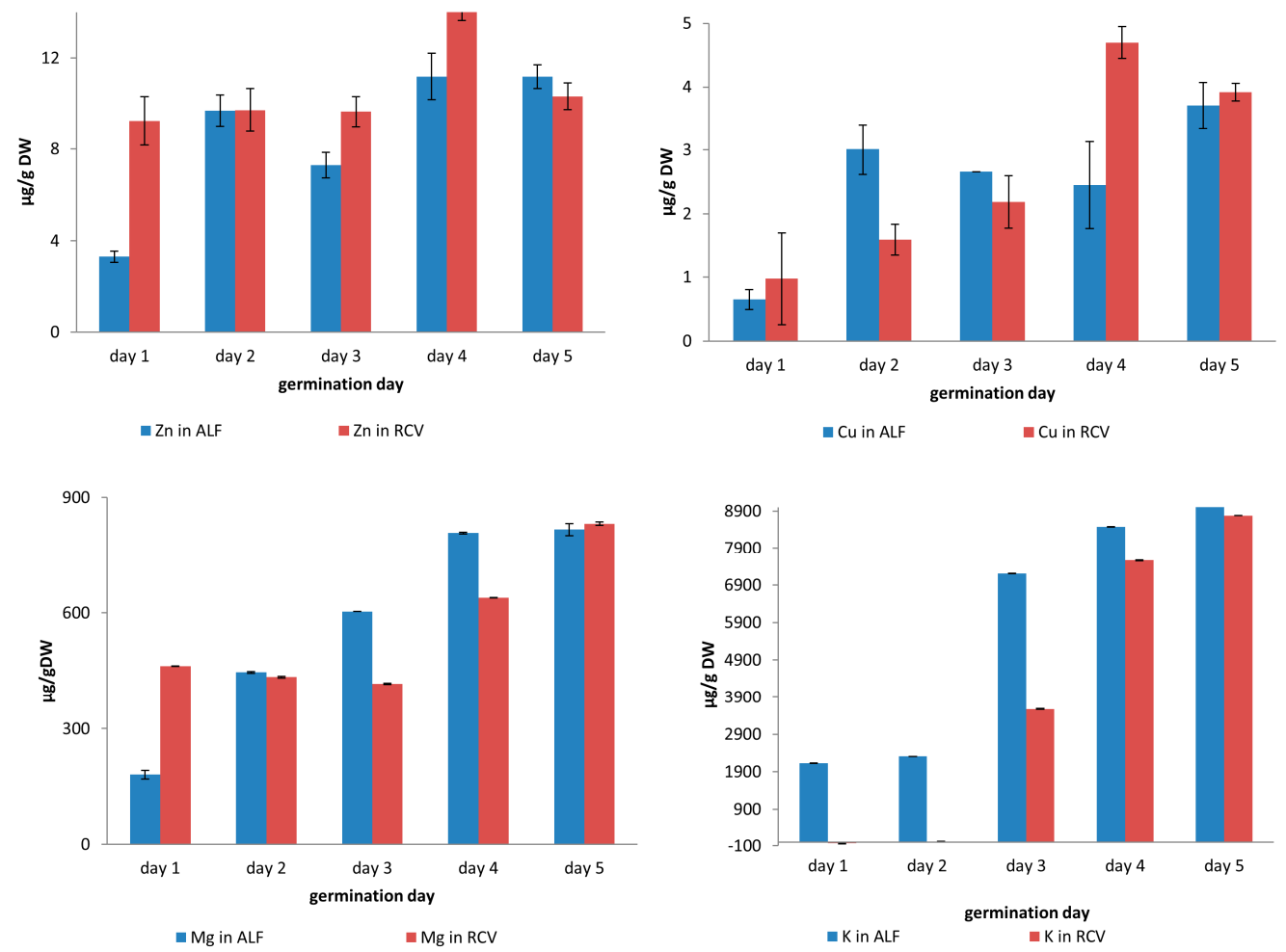

Figure 2. Relative change per day in $\mathrm{Zn}, \mathrm{Cu}, \mathrm{Mg}$, and $\mathrm{K}$ content in sprouts of ALF and RCV during germination, compared to row seeds.
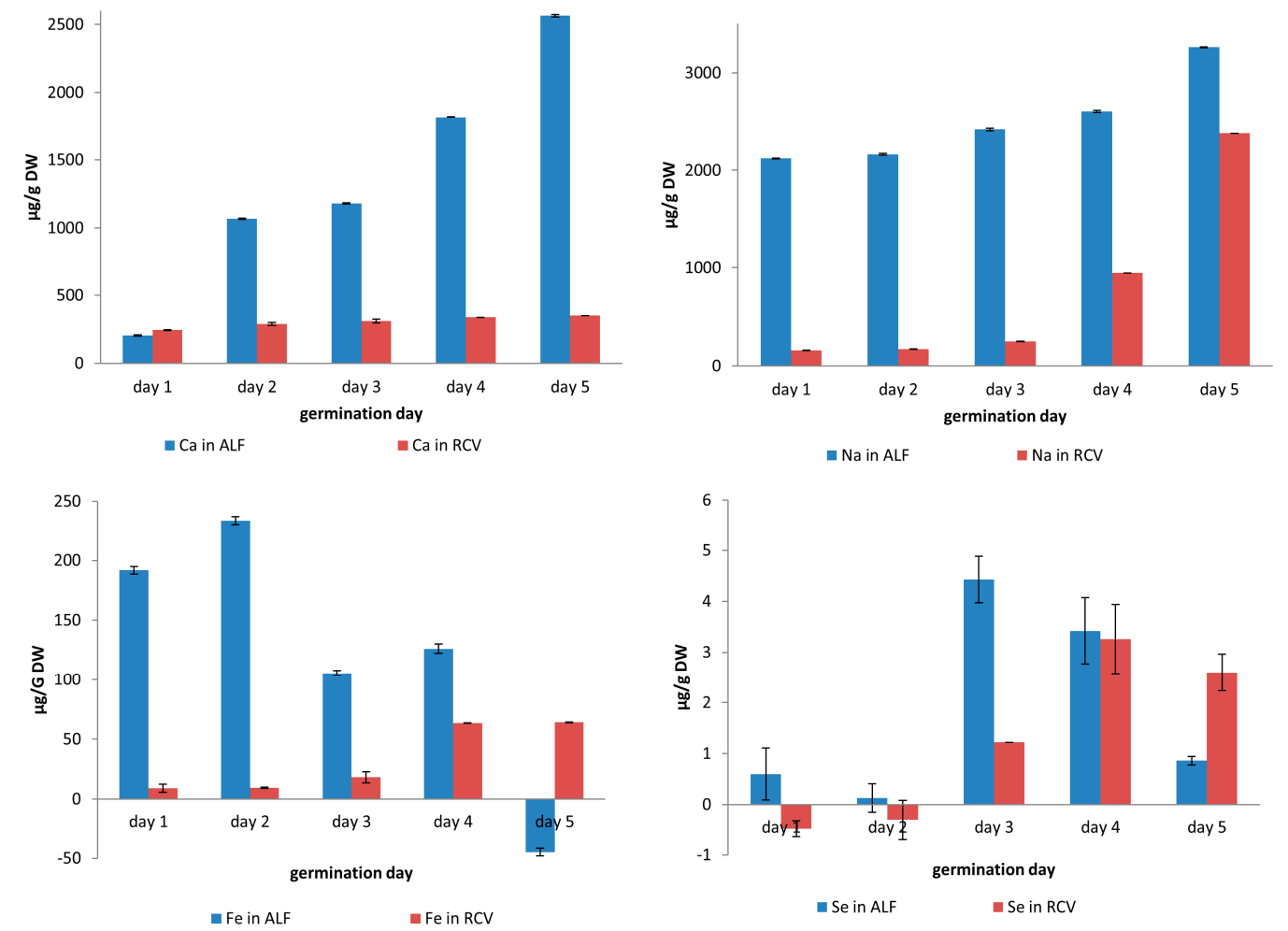

Figure 3. Relative change per day in $\mathrm{Ca}, \mathrm{Na}, \mathrm{Fe}$, and Se content in sprouts of ALF and RCV during germination, compared to row seeds. 
While in RCV sprouts there is a slight increase in the calcium concentration during the 5-day germination, in ALF, a significant increase after the first day of germination can be observed compared with raw seeds. This difference is maintained trend-wise up to a value of 13.7 folds compared to the ALF seeds. In a similar manner, Mn exhibits a constant slightly increase in RCV, although in ALF an important increase was noted from the third germination day up to a value 1.5-fold higher than in seeds.

RCV sprouts exhibited a moderate but constant increase in Fe amounts compared with raw seeds starting from the third day of germination, while for ALF sprouts, a significant increase $(p<0.05)$ was observed coming out of the first day of germination and reaching a maximum in the second day (2.8-fold compared to seeds), followed by a decrease in this amounts below the value measured in the seeds, in the fifth day of germination. A significant decrease in Fe content was mentioned in black and white beans (Phaseolus vulgaris L.) and in pigeon beans (Cajanus cajan L. Millsp) sprouts after 5 days of germination compared to seeds [25].

$\mathrm{Zn}, \mathrm{Ni}$, and $\mathrm{Cu}$ followed the same pattern of slow increase, reaching the maximum in the fouth day of germination, noting that, while for $\mathrm{Cu}$ approximately identical concentrations were measured for both plant species, for ALF higher concentration values of $\mathrm{Zn}$ and Ni were recorded.

Regarding Se, although the values of the concentrations in the seeds of both plants are approximately equal, the dynamic during the germination was different, with an increase until the third day followed by a decrease during the last two days in ALF sprouts, compared to a decrease in the first two days in RCV. A higher value was reached in ALF (11.42 $\mu \mathrm{g} / \mathrm{g}$ DW) compared to RCV $(7.38 \mu \mathrm{g} / \mathrm{g} \mathrm{DW})$ in the third day of germination.

This finding was in an agreement with previously reported data on the dynamic changes of elemental profile during germination in different plant species. Studies showed increases in most of the mineral elements during germination in cereals like buckwheat and wheat sprout [15,29], sunflower sprouts [30], Cruciferae sprouts [31] and soybean sprouts [15,32]. The differences in mineral content may be due to the loss in dry weight and increase in the proportion of inorganic matter and decrease in organic nutrient during sprouting, and hence can be treated as apparent [14]. On the other hand, considerable translocation of individual mineral elements occurs during sprouting and changes in solubilization may influence extractability and bioavailability of minerals [14]. It is known that germinated leguminous crops are highly nutritious for their enhanced minerals and trace elements bioavailability due to the reduction in phytates [33].

Among multiple variables influencing trace-element bioavailability, as well as tannins and phytates, polyphenols are reported to chelate metals, reducing the bioavailability of minerals [34]. There is very little information on the effect of dietary polyphenolic compounds on the status of trace elements. Since ALF and RCV sprouts are a good source of both polyphenols and minerals, future studies on the bioavailability of the trace elements from sprouts are essential to exploring their potential to modulate human metabolism.

In terms of absolute values measured in the analyzed samples, few references allow comparisons with the literature. Plaza, [15] investigated the nutritional compounds in sprouts and seeds of soybean, alfalfa, and wheat after 4 days of germination. The results for ALF revealed concentrations of $17.79 \mu \mathrm{g} / \mathrm{g}$ for $\mathrm{Mn}, 53.3 \mu \mathrm{g} / \mathrm{g}$ for $\mathrm{Zn}$, and $17.77 \mu \mathrm{g} / \mathrm{g}$ for $\mathrm{Cu}$, which are close to our results. Values for Fe $(153.7 \mu \mathrm{g} / \mathrm{g})$ and $\mathrm{Ca}(332 \mu \mathrm{g} / \mathrm{g})$ were lower than in our study, while the value for $\mathrm{Na}(4720 \mu \mathrm{g} / \mathrm{g})$ exceeded our result. Minerals concentration measured in mug bean sprouts after 3 days of germination exhibited values of $601.0 \mu \mathrm{g} / \mathrm{g}$ for $\mathrm{Ca}, 759 \mu \mathrm{g} / \mathrm{g}$ for $\mathrm{Fe}, 17.4 \mu \mathrm{g} / \mathrm{g}$ for $\mathrm{Mn}$, and $67 \mu \mathrm{g} / \mathrm{g}$ for $\mathrm{Zn}$ [35]. The values measured for ALF during our study exceeded the concentration of $\mathrm{Ca}$ in the above reported study but are lower for Fe and Mn. RCV sprouts showed lower concentration for all of them in comparison with the results of Tiwari [35]. Study on the composition of mineral elements in buckwheat and wheat sprouts [29], revealed concentration values lower than in ALF and RCV sprouts for $\mathrm{Na}, \mathrm{K}, \mathrm{Fe}$, and $\mathrm{Ni}$, higher for $\mathrm{Mg}$ and $\mathrm{Zn}$ in buckwheat sprouts, and close concentration values for $\mathrm{Zn}$ and $\mathrm{Ca}$ in wheat sprouts. The elemental profile in common white bean seeds, obtained by Koplík, [36] displayed values of 
$1610 \mu \mathrm{g} / \mathrm{g}$ for Mg, 14,100 $\mu \mathrm{g} / \mathrm{g}$ for K, $2060 \mu \mathrm{g} / \mathrm{g}$ for Ca, $101 \mu \mathrm{g} / \mathrm{g}$ for Fe, $18 \mu \mathrm{g} / \mathrm{g}$ for Mn, $0.11 \mu \mathrm{g} / \mathrm{g}$ for Se, and $6.74 \mu \mathrm{g} / \mathrm{g}$ for $\mathrm{Zn}$. Except $\mathrm{K}, \mathrm{Ca}$, and $\mathrm{Mn}$, all elements showed considerably higher concentrations both in seeds and sprouts for both plants species in the current investigation.

The present study showed important concentrations of macro-minerals and trace elements which, along with significant amounts of phytoestrogens, make the sprouts of ALF and RCV a functional food able to provide effective means to prevent diseases and improve quality of life through biomolecules. Thus, along with other studies that recommend the consumption of sprouts or extracts of RCV in the treatment of menopausal disorders based on the content of isoflavones with estrogenic action $[1,4,37]$, the present research reinforces the role that RCV can play in the prevention of menopause-related disturbances and diseases through the mineral content as well, and show the potential of ALF sprouts to be used as nutraceutical in pre/post-menopausal disorders.

\subsection{Multivariate Statistical Analysis}

For exploratory data analysis purposes, principal components analysis (PCA) and Hierarchical Cluster Analysis (HCA) were used as unsupervised statistical methods in order to discriminate between the RCV and ALF sprouts samples during germination, based on the total polyphenols (TP), anti-radical activity (AA), sum of isoflavones with estrogenic activity, and elemental profile composition (Ca, $\mathrm{K}$, $\mathrm{Mg}, \mathrm{Na}, \mathrm{Fe}, \mathrm{Zn}, \mathrm{Se}, \mathrm{Ag}, \mathrm{Ni}, \mathrm{Zn}, \mathrm{Mn}$, and $\mathrm{Cu}$ ).

The first two principal components (PC 1 and PC 2) with $68.34 \%$ of the whole variances were extracted from PCA analysis. PC 1 accounted for $46.78 \%$ variances and PC 2 accounted for $21.56 \%$. The other principal components that had a minor effect on the model were discarded. The distribution in the PC1-PC2 score plot plane of the RCV and ALF sprouts samples during germination is presented in Figure 4.

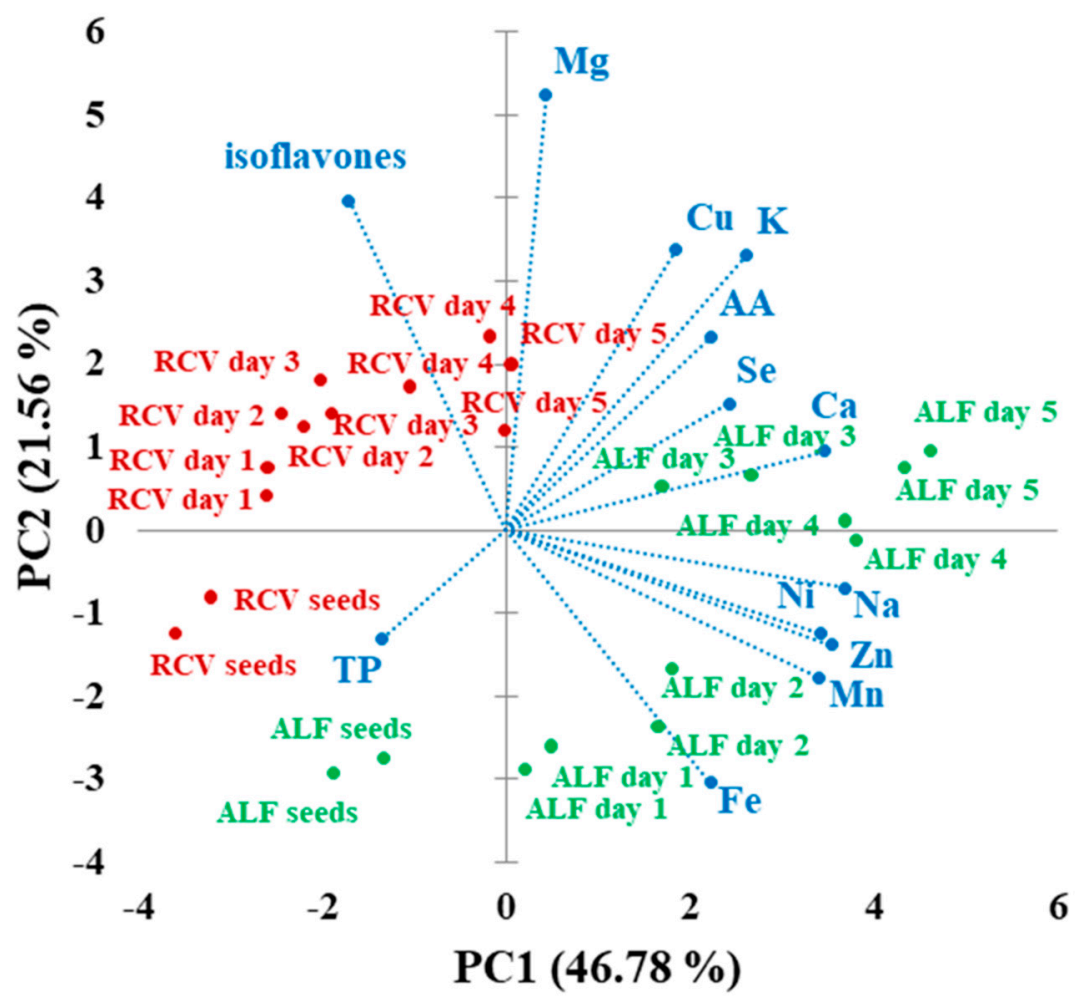

Figure 4. Principal Component Analysis (PCA) of the RCV and ALF sprouts samples during 5 days of germination based on total polyphenols (TP), anti-radical activity (AA), and the sum of isoflavones with estrogenic activity and elemental profile composition. 
Along PC1 can be discriminated the RCV seeds from the RCV sprouts corresponding to the 5 days of germination, and also the ALF seeds and ALF sprouts corresponding to the first 2 days of germination from ALF sprouts corresponding to the last 3 days of germinations. It can be noticed that the elemental profile and AA have the highest contribution to the total variation, along PC1, while TP and isoflavones with estrogenic activity have a lower contribution.

Along PC2 axis can be discriminated two clusters, corresponding to the ALF sprouts, except the ALF seeds, on the right side and RCV sprouts on the left side. The elemental profile and AA have the highest contribution for the discrimination of ALF samples, while isoflavones with estrogenic activity and TP contribute to the discrimination of RCV samples during the germination. PCA analysis revealed the correlations among the elemental composition and bioactive potential of sprouts. Our results revealed that $\mathrm{Mg}, \mathrm{Cu}, \mathrm{K}$, and isoflavones with estrogenic activity are representative for $\mathrm{RCV}$ sprouts in the fourth and the fifth day of germination, while $\mathrm{Fe}, \mathrm{Mn}, \mathrm{Zn}, \mathrm{Ni}, \mathrm{Na}, \mathrm{Ca}$, and Se characterize the ALF sprouts during the germination process. TP characterizes the RCV seeds and ALF seeds.

Hierarchical Cluster Analysis using Ward's method and Euclidean distance was used to assess the dissimilarities between ALF and RCV sprouts samples during 5 days of germination based on total polyphenols (TP), anti-radical activity (AA), and sum of isoflavones with estrogenic activity and elemental profile composition. The dendrogram (Figure 5) shows the clustering of the investigated samples in three separated classes: class 1 (C1) refers to the ALF seeds, RCV seeds, and RCV sprouts corresponding to the first two days of germination; class 2 (C2) include ALF sprouts corresponding for the first 2 days of germination and RCV day 3; class 3 (C) grouped together the RCV sprouts corresponding to the fourth and fifth day of germination and ALF sprouts from day 3 to day 5 of germination.

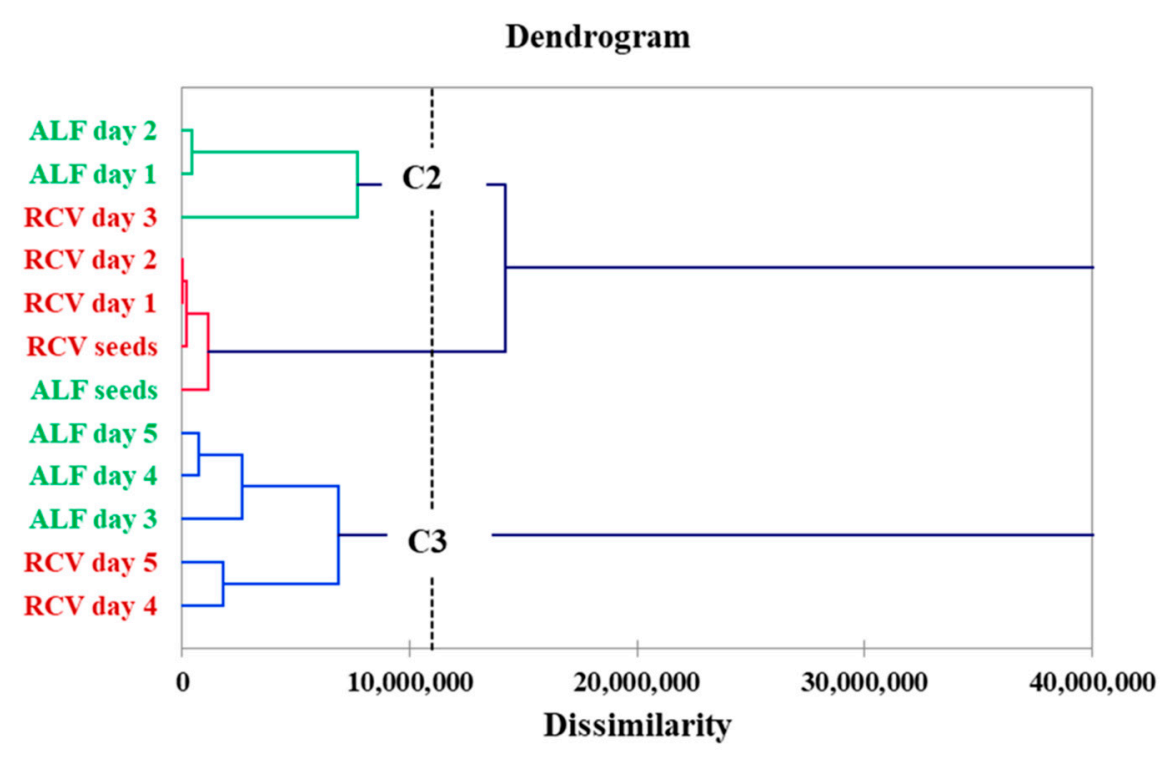

Figure 5. Dendrogram of the ALF and RCV sprouts samples during 5 days of germination: C1, 2, 3-classes grouped by dissimilarities criteria.

\section{Materials and Methods}

\subsection{Plant Samples—Germination}

The germination method was described in the previous published study [23] of the authors. In summary, approximately $50 \mathrm{~g}$ of seed of each plant species were washed with $20{ }^{\circ} \mathrm{C}$ sterile distilled water for $30 \mathrm{~min}$ and then placed into a growth chamber of an automat sprout germinator, (Biovita model GE-1, Cluj-Napoca, Romania). Germination took place at $25{ }^{\circ} \mathrm{C}$ and $80 \%$ relative humidity in dark conditions. Seed hydration was automatically controlled as follows: the seeds, 
previously soaked in distilled water for $7 \mathrm{~h}$, were irrigated with distilled water every $5 \min$ for $7 \mathrm{~h}$, then, for $1 \mathrm{~min}$ every $4 \mathrm{~h}$. For both plant species we obtained and collected sprouts at $24 \mathrm{~h}, 48 \mathrm{~h}, 72 \mathrm{~h}, 96 \mathrm{~h}$, and 120h, which were immediately dried for $4.5 \mathrm{~h}$ at $40^{\circ} \mathrm{C}$ using a fruit dryer (Zilan model- ZLN-9645l). Average humidity loss was $90 \%$ for ALF and $89 \%$ for RCV. Aliquots of $5 \mathrm{~g}$ portion of each seeds and sprouts sample were ground using an electric grinder (Bosh, Germany) for $3 \mathrm{~min}$ and immediately subjected to analysis.

\subsection{Total Polyphenols (TP) and Anti-Radical Activity (AA)}

In order to estimate the bioactive properties of RCV and ALF sprout, plant material was extracted using an ultrasonic assisted extraction (UAE) method optimized in a previous study of Chiriac [23]. An ultrasonic bath (MRC Scientific Instruments DCG-120H, UK) at ultrasonication power of $70 \mathrm{~W}$ and frequency of $60 \mathrm{~Hz}$ was used for the extraction at temperature of $40{ }^{\circ} \mathrm{C}$ for $60 \mathrm{~min}$. Ethanol $70 \%(v / v)$ was used as the extraction solvent with a ratio of liquid to solid of 1:10 $\mathrm{g}$ DW/g. The extraction was done in duplicate.

Isoflavones with estrogenic activity (genistin, genistein, daidzin, daidzein, formononetin, glycitein, and myricetin) were quantified in the extracts as mentioned in detail in a previous study [23] by applying ultra-high performance liquid chromatography-Q Exactive hybrid quadrupole-Orbitrap high resolution accurate mass spectrometry operated in negative ionization using a $v$ DIA (variable data independent acquisition) approach.

\subsubsection{Determination of Total Polyphenols (TP)}

The total polyphenolic content (TP) of the ethanolic extracts of each sprout sample was determined by spectrophotometric method using the Folin-Ciocalteu method as described by Vlaisavljević [5]. Accordingly, $1 \mathrm{~mL}$ of each sprout extract or standard solution was mixed with $5 \mathrm{~mL}$ of $0.1 \mathrm{~mol} / \mathrm{L}$ Folin-Ciocâlteu (FC) reagent and $4 \mathrm{~mL}$ of $\mathrm{Na}_{2} \mathrm{CO}_{3}(75 \mathrm{~g} / \mathrm{L})$. The mixture was allowed to stand for $2 \mathrm{~h}$ at room temperature. Samples were then centrifuged at $2000 \times g$ for $5 \mathrm{~min}$ and the absorbance of supernatant was measured at $760 \mathrm{~nm}$ using an UV-VIS spectrometer (UV-2600i, Shimadzu, Shimatzu Europa GmbH, Germany). The TP was determined by comparison with a standard calibration curve of gallic acid (10 to $100 \mu \mathrm{g} / \mathrm{mL}$ in ethanol $70 \% v / v$ ) and the results were expressed as mg of gallic acid equivalents (GAE)/gram of dry weight (DW) sample. All determinations were performed in duplicate.

\subsubsection{Anti-Radical Activity (DPPH assay)}

The anti-radical activity (AA) was determined by DPPH method described by Brand-Williams [38]. The DPPH solution was prepared by dissolving (phenyl)-(2,4,6-trinitrophenyl) iminoazanium in methanol to $6 \times 10^{-5} \mathrm{M}$ concentration. $0.1 \mathrm{~mL}$ ethanolic extract of each sprout sample was mixed with $3.9 \mathrm{~mL} \mathrm{M}$ DPPH solution and, after $30 \mathrm{~min}$, the absorbance was measured at $515 \mathrm{~nm}$. The results were expressed as percentage of DPPH $\bullet$ elimination calculated according to the relation: $\{[(\mathrm{Ac}-\mathrm{At}) / \mathrm{Ac}] \cdot 100\}$, where Ac is the absorbance of the control and At is the absorbance of the plant extracts. All determinations were performed in duplicate.

\subsection{Elemental Content Determination}

\subsubsection{Microwave Acid Digestion of Plant Material}

In order to estimate the elemental content of RCV and ALF sprout, plant material was extracted by microwave acid digestion using a TOP microwave sample preparation system (Analytik Jena) equipped with closed Teflon vessels. For the acid digestion procedure, $0.4 \mathrm{~g}$ sample was placed in the Teflon digestion vessel previously cleaned with $10 \%$ nitric acid. Then, $7.5 \mathrm{~mL}$ of concentrated nitric acid 65\% (spectroscopic grade, Merck, Darmstadt, Germany) were added. The vessels were closed and placed in the rotor, followed by the application of the digestion program (Table 3). After the 
digestion process, each digested sample was quantitatively transferred with ultra-pure water into a $50 \mathrm{~mL}$ volumetric flask.

Table 3. Parameters of digestion process.

\begin{tabular}{cccccc}
\hline Step & Power $(\%)$ & Ramp (min) & Pressure (bar) & Temperature $\left({ }^{\circ} \mathbf{C}\right)$ & Time $(\mathbf{m i n})$ \\
\hline 1 & 80 & 5 & 40 & 170 & 10 \\
2 & 90 & 1 & 40 & 200 & 15 \\
\hline
\end{tabular}

\subsubsection{Analytical Determinations}

The determination of the amount of $\mathrm{Ca}, \mathrm{Mg}, \mathrm{Cu}, \mathrm{Ni}, \mathrm{Fe}, \mathrm{Mn}, \mathrm{Na}, \mathrm{K}$, and $\mathrm{Zn}$ in ALF and RCV seeds and sprouts samples was carried out by flame atomic absorption spectroscopy (F-AAS) NOVAA 300 model with Air- $\mathrm{C}_{2} \mathrm{H}_{2}$ flame, while the determination of Se was done using a graphite furnace atomic absorption spectrophotometer (GF-AAS) Model Zeenit 650 equipped with Zeeman background correction facility. As the radiation sources, hallow cathode lamps of the different metals were used. The analytical measurements were based on time-averaged absorbance. Resonance lines at 422.7, 285.2, 324.8, 232.0, 248.3, 279.5, 589.0, 766.5, and 213.9 nm were employed for $\mathrm{Ca}, \mathrm{Mg}, \mathrm{Cu}, \mathrm{Ni}, \mathrm{Fe}, \mathrm{Mn}$, $\mathrm{Na}, \mathrm{K}$, and $\mathrm{Zn}$. Lamp intensity (4-6 mA) and band pass (0.2-0.5 nm) were used. Air/acetylene flow rates were between $0.9-1.1 \mathrm{~L} / \mathrm{min}$ for all metals. The digested samples were directly injected into the spectrophotometer. External calibration curves were set up for each of the elements. Calibration solutions were prepared by successive dilution of a high purity multielement calibration standard solutions $\left(1000 \mathrm{mg} / \mathrm{L}\right.$ of each element in $\mathrm{HNO}_{3} 65 \%$, ICP Multi-Element Standard Solution IV CertiPUR ${ }^{\circledR}$ and $10 \mathrm{mg} / \mathrm{L}$ of each element in $\mathrm{HNO}_{3}$ 65\%, ICP Multi-Element Standard Solution XXI CertiPUR ${ }^{\circledR}$, Merck KGaA Frankfurter, Darmstadt, Germany). Ultrapure water with a maximum resistivity of 18.2 $\mathrm{M} \Omega / \mathrm{cm}$ was used for dilution. All the obtained calibration curves were characterized by a high correlation coefficient $\left(\mathrm{R}^{2}>0.995\right)$ and the value of standard deviation $<10 \%$. All determinations were performed in two independent replicates.

\subsection{Statistical Analysis}

The obtained analytical data were processed statistically by analysis of variance (ANOVA) and used for the evaluation of the significant differences among different samples of RCV and ALF sprouts extracts. The Duncan's test was used to discriminate the samples (differences at $p<0.05$ were considered to be significant). Also, Principal Component Analysis (PCA) and Hierarchical Clustering analysis (HCA) (Euclidean distance and Ward's method) were performed in order to discriminate between the germination stages of the selected plants based on agglomerative hierarchical clustering (AHC) and discriminant analysis (DA) method presented by Popescu [39]. All the mathematical and statistical analyses were performed using Microsoft Excel 2010 and XLSTAT Add in soft version 15.5.03.3707.

\section{Conclusions}

In the present study, we identified changes in mineral element and bioactive properties of the of Trifolium pratense L. and Medicago sativa L. sprouts during germination with an increased bioactivity and mineral content. The anti-radical activity, expressed as DPPH• free radical inhibition percentages, significantly increased in the extracts of both ALF and RCV sprouts during germination, reaching a maximum in the second day of germination for RCV (45.12\%) and in the third day for ALF (60.7\%). The highest total polyphenols content was $23.34 \mathrm{mg}$ gallic acid eq/g DW in RCV sprouts recorded in the fourth day of germination, while in ALF the highest level of $18.51 \mathrm{mg}$ gallic acid eq/g DW was reached in the third day.

Both ALF and RCV sprouts were found to be rich in major mineral elements like $\mathrm{Mg}, \mathrm{K}, \mathrm{Na}$, and $\mathrm{Ca}$, and trace elements such as $\mathrm{Zn}, \mathrm{Fe}, \mathrm{Cu}, \mathrm{Ni}$, and $\mathrm{Se}$. The content of $\mathrm{Ca}, \mathrm{Na}, \mathrm{Fe}$, and Se in ALF sprouts was significantly $(p<0.05)$ higher than in RCV sprouts. Large differences in the mineral 
content were found between plant species and during the germination. $\mathrm{Ca}, \mathrm{Se}, \mathrm{Fe}, \mathrm{K}$, and $\mathrm{Ni}$ levels increased in ALF during germination while in $\mathrm{RCV}$, germination resulted in increased $\mathrm{Na}, \mathrm{K}, \mathrm{Cu}, \mathrm{Ni}$, and Se levels. PCA analysis showed that $\mathrm{Mg}, \mathrm{Cu}$, and $\mathrm{K}$ are representative for $\mathrm{RCV}$ sprouts in the fourth and fifth day of germination, while $\mathrm{Fe}, \mathrm{Mn}, \mathrm{Zn}, \mathrm{Ni}, \mathrm{Na}, \mathrm{Ca}$, Se characterize the ALF sprouts.

The phytochemicals and anti-radical activities of sprouts were considerable depending on the germination process. The third and fourth day germinated sprouts may provide the best potential value targeting beneficial heath.

Overall, our research has confirmed the nutritional features of Trifolium pratense L. and Medicago sativa L. sprouts and highlighted their potential to be considered as functional food products and nutraceuticals.

Supplementary Materials: The following are available online at http://www.mdpi.com/2076-3417/10/20/7249/s1, Table S1: Total polyphenols, anti-radical activity and sum of isoflavones with estrogenic activity (genistin, genistein, daidzin, daidzein, formononetin, glycitein, myricetin) in ALF and RCV seeds and sprouts during germination (ALF and RCV samples coded as: day 1-first day of germination; day 2-s day of germination; day 3-third day of germination; day 4-fourth day of germination; day 5-fith day of germination); Table S2. Correlation matrix between bioactive properties of RCV seeds and sprouts corresponding to different germination stages; Table S3. Correlation matrix between bioactive properties of ALF seeds and sprouts corresponding to different germination stages; Figure S1: Relative changes in the Ni and Mn content in sprouts of ALF and RCV during germination compared to row seeds. All authors have read and agreed to the published version of the manuscript.

Author Contributions: Conceptualization, E.R.C. and C.L.C.; methodology, C.S.; software, E.-I.G., D.B.; validation, E.-I.G., C.L.C. and E.R.C.; formal analysis, M.L.; investigation, E.R.C.; resources, E.R.C.; data curation, M.D.; writing-original draft preparation, E.R.C.; writing—review and editing, E.R.C., C.L.C. and E.-I.G.; visualization, C.E.G., D.B.; supervision, R.B. All authors are read and agreed to the published version of the manuscript.

Funding: This research received no external funding.

Acknowledgments: Elisabeta-Irina Geana is grateful to the Operational Programme Human Capital of the Ministry of European Funds through the Financial Agreement 51668/09.07.2019, SMIS code 124705.

Conflicts of Interest: The authors declare no conflict of interest.

\section{References}

1. Spanguolo, P.; Rasini, E.; Luini, A.; Legnaro, M.; Luzzani, M.; Casareto, E.; Carreri, M.; Paracchini, S.; Marino, F.; Cosentino, M. Isoflavone content and estrogenic activity of different batches of red clover (Trifolium pretense L.) extracts: An in vitro study in MCF-7 cells. Fitoterapia 2014, 94, 62-69.

2. Clifton-Bligh, P.B.; Nery, M.-L.; Clifton-Bligh, R.J.; Visvalingam, S.; Fulcher, G.R.; Byth, K.; Baber, R. Red clover isoflavones enriched with formononetin lower serum LDL cholesterol-A randomized, double-blind, placebo-controlled study. Eur. J. Clin. Nutr. 2014, 69, 134-142. [CrossRef]

3. Rafińska, K.; Pomastowski, P.; Wrona, O.; Górecki, R.; Buszewski, B. Medicago sativa as a source of secondary metabolites for agriculture and pharmaceutical industry. Phytochem. Lett. 2017, 20, 520-539. [CrossRef]

4. Çölgeçen, H.; Koca, U.; Büyükkartal, H. Use of Red Clover (Trifolium pratense L.) Seeds in Human Therapeutics. In Nuts and Seeds in Health and Disease Prevention; Elsevier: Amsterdam, The Netherlands, 2020; pp. 421-427.

5. Vlaisavljević, S.; Kaurinovic, B.; Popovic, M.; Vasiljević, S. Profile of phenolic compounds in Trifolium pratense L. extracts at different growth stages and their biological activities. Int. J. Food Prop. 2017, 20, 3090-3101. [CrossRef]

6. Ferraris, C.; Ballestra, B.; Cappelletti, V.; Listorti, C.; Miodini, P.; Pulice, I.; Mariani, L.; Ferrari, E.; Gambaro, A.; Maugeri, I.; et al. Use of red clover in premenopausal breast cancer patients receiving hormonal adjuvant treatment: Biological and clinical implications from a randomized clinical trial. Ann. Oncol. 2018, 29 , viii80. [CrossRef]

7. Booth, N.L.; Piersen, C.E.; Banuvar, S.; Geller, S.E.; Shulman, L.P.; Farnsworth, N.R. Clinical studies of red clover (Trifolium pratense) dietary supplements in menopause: A literature review. Menopause 2006, 13, 251-264. [CrossRef] [PubMed]

8. Hošek, J.; Šmejkal, K. Flavonoids as Anti-inflammatory Agents. In Encyclopedia of Inflammatory Diseases; Parnham, M., Ed.; Birkhäuser: Basel, Switzerland, 2015. 
9. Shi, Y.; Guo, R.; Wang, X.; Yuan, D.; Zhang, S.; Wang, J.; Yan, X.; Wang, C. The Regulation of Alfalfa Saponin Extract on Key Genes Involved in Hepatic Cholesterol Metabolism in Hyperlipidemic Rats. PLoS ONE 2014, 9, e88282. [CrossRef]

10. Cornara, L.; Ulrih, N.P.; Burlando, B. Therapeutic Potential of Temperate Forage Legumes: A Review. Crit. Rev. Food Sci. Nutr. 2015, 56, S149-S161. [CrossRef]

11. Silva, L.R.; Pereira, M.J.; Azevedo, J.; Gonçalves, R.F.; Valentão, P.; De Pinho, P.G.; Andrade, P.B. Glycine $\max ($ L.) Merr., Vigna radiata L. and Medicago sativa L. sprouts: A natural source of bioactive compounds. Food Res. Int. 2013, 50, 167-175. [CrossRef]

12. Nelson, K.; Stojanovska, L.; Vasiljevic, T.; Mathai, M. Germinated grains: A superior whole grain functional food? Can. J. Physiol. Pharmacol. 2013, 91, 429-441. [CrossRef]

13. Gan, R.-Y.; Lui, W.-Y.; Wu, K.; Chan, C.-L.; Dai, S.-H.; Sui, Z.-Q.; Corke, H. Bioactive compounds and bioactivities of germinated edible seeds and sprouts: An updated review. Trends Food Sci. Technol. 2017, 59, 1-14. [CrossRef]

14. Chavan, J.K.; Kadam, S.S.; Beuchat, L.R. Nutritional improvement of cereals by sprouting. Crit. Rev. Food Sci. Nutr. 1989, 28, 401-437. [CrossRef] [PubMed]

15. Plaza, L.; De Ancos, B.; Cano, P.M. Nutritional and health-related compounds in sprouts and seeds of soybean (Glycine max), wheat (Triticum aestivum L.) and alfalfa (Medicago sativa) treated by a new drying method. Eur. Food Res. Technol. 2003, 216, 138-144. [CrossRef]

16. Luo, Y.-W.; Xie, W. Effect of soaking and sprouting on iron and zinc availability in green and white faba bean (Vicia faba L.). J. Food Sci. Technol. 2013, 51, 3970-3976. [CrossRef]

17. Ferrari, C.; Torres, E. Biochemical pharmacology of functional foods and prevention of chronic diseases of aging. Biomed. Pharmacother. 2003, 57, 251-260. [CrossRef]

18. El-Deeb, M.M.K.; El-Sheredy, H.G.; Mohammed, A.F. The Role of Serum Trace Elements and Oxidative Stress in Egyptian Breast Cancer Patients. Adv. Breast Cancer Res. 2016, 5, 37-47. [CrossRef]

19. Terry, P.D.; Qin, B.; Camacho, F.; Moorman, P.G.; Alberg, A.J.; Barnholtz-Sloan, J.S.; Bondy, M.; Cote, M.L.; Funkhouser, E.; Guertin, M.J.; et al. Supplemental Selenium May Decrease Ovarian Cancer Risk in African-American Women. J. Nutr. 2017, 147, 621-627. [CrossRef]

20. Lomagno, K.A.; Hu, F.; Riddell, L.J.; Booth, A.O.; Szymlek-Gay, E.A.; Nowson, C.A.; Byrne, L.K. Increasing Iron and Zinc in Pre-Menopausal Women and Its Effects on Mood and Cognition: A Systematic Review. Nutrients 2014, 6, 5117-5141. [CrossRef]

21. Szkup, M.; Jurczak, A.; Brodowska, A.; Brodowska, A.; Noceń, I.; Chlubek, D.; Laszczyńska, M.; Karakiewicz, B.; Grochans, E. Analysis of Relations Between the Level of Mg, Zn, Ca, Cu, and Fe and Depressiveness in Postmenopausal Women. Biol. Trace Element Res. 2016, 176, 56-63. [CrossRef]

22. Mattioli, S.; Bosco, A.D.; Martino, M.; Ruggeri, S.; Marconi, O.; Sileoni, V.; Falcinelli, B.; Castellini, C.; Benincasa, P. Alfalfa and flax sprouts supplementation enriches the content of bioactive compounds and lowers the cholesterol in hen egg. J. Funct. Foods 2016, 22, 454-462. [CrossRef]

23. Chiriac, E.R.; Chiţescu, C.L.; Borda, D.; Lupoae, M.; Gird, C.E.; Geana, E.-I.; Blaga, G.-V.; Boscencu, R. Comparison of the Polyphenolic Profile of Medicago sativa L. and Trifolium pratense L. Sprouts in Different Germination Stages Using the UHPLC-Q Exactive Hybrid Quadrupole Orbitrap High-Resolution Mass Spectrometry. Molecules 2020, 25, 2321. [CrossRef]

24. Butkutè, B.; Taujenis, L.; Norkevičienè, E. Small-Seeded Legumes as a Novel Food Source. Variation of Nutritional, Mineral and Phytochemical Profiles in the Chain: Raw Seeds-Sprouted Seeds-Microgreens. Molecules 2018, 24, 133. [CrossRef] [PubMed]

25. Sangronis, E.; Machado, C. Influence of germination on the nutritional quality of Phaseolus vulgaris and Cajanus cajan. LWT 2007, 40, 116-120. [CrossRef]

26. Narina, S.S.; Hamama, A.A.; Bhardwaj, H.L. Nutritional and Mineral Composition of Flax Sprouts. J. Agric. Sci. 2012, 4, 60. [CrossRef]

27. Oh, M.-M.; Rajashekar, C.B. Antioxidant content of edible sprouts: Effects of environmental shocks. J. Sci. Food Agric. 2009, 89, 2221-2227. [CrossRef]

28. Ti, H.; Zhang, R.; Zhang, M.; Li, Q.; Wei, Z.; Zhang, Y.; Tang, X.; Deng, Y.; Liu, L.; Ma, Y. Dynamic changes in the free and bound phenolic compounds and antioxidant activity of brown rice at different germination stages. Food Chem. 2014, 161, 337-344. [CrossRef] 
29. Pongrac, P.; Potisek, M.; Fraś, A.; Likar, M.; Budič, B.; Myszka, K.; Boros, D.; Necemer, M.; Kelemen, M.; Vavpetič, P.; et al. Composition of mineral elements and bioactive compounds in tartary buckwheat and wheat sprouts as affected by natural mineral-rich water. J. Cereal Sci. 2016, 69, 9-16. [CrossRef]

30. Tiyayon, P.; Duangmal, K. Changes in chemical composition, minerals, total phenolic compounds and antioxidant activities during germination of sunflower sprout. Acta Hortic. 2018, 527-532. [CrossRef]

31. Zielinski, H.; Frias, J.; Piskuła, M.K.; Kozłowska, H.; Vidal-Valverde, C. Vitamin B1 and B2, dietary fiber and minerals content of Cruciferae sprouts. Eur. Food Res. Technol. 2005, 221, 78-83. [CrossRef]

32. Özcan, M.M.; Al-Juhaimi, F. Effect of sprouting and roasting processes on some physico-chemical properties and mineral contents of soybean seed and oils. Food Chem. 2014, 154, 337-342. [CrossRef]

33. Bains, K.; Uppal, V.; Kaur, H. Optimization of germination time and heat treatments for enhanced availability of minerals from leguminous sprouts. J. Food Sci. Technol. 2011, 51, 1016-1020. [CrossRef]

34. Leopoldini, M.; Russo, N.; Toscano, M. The molecular basis of working mechanism of natural polyphenolic antioxidants. Food Chem. 2011, 125, 288-306. [CrossRef]

35. Tiwari, U.; Servan, A.; Nigam, D. Comparative study on antioxidant activity, phytochemical analysis and mineral composition of the Mung Bean (Vigna Radiata) and its sprouts. J. Pharmacogn. Phytochem. 2017, 6, 336-340.

36. Koplík, R.; Pavelková, H.; Cincibuchová, J.; Mestek, O.; Kvasnička, F.; Suchanek, M. Fractionation of phosphorus and trace elements species in soybean flour and common white bean seeds by size exclusion chromatography-inductively coupled plasma mass spectrometry. J. Chromatogr. B 2002, 770, 261-273. [CrossRef]

37. Kolodziejczyk-Czepas, J. Trifolium species-The latest findings on chemical profile, ethnomedicinal use and pharmacological properties. J. Pharm. Pharmacol. 2016, 68, 845-861. [CrossRef] [PubMed]

38. Brand-Williams, W.; Cuvelier, M.; Berset, C. Use of a free radical method to evaluate antioxidant activity. LWT 1995, 28, 25-30. [CrossRef]

39. Popescu, R.; Ionete, R.E.; Dinca, O.R.; Costinel, D.; Bucura, F.; Geana, E.-I.; Alabedallat, Y.F.J.; Botu, M. ${ }^{1} \mathrm{H}-\mathrm{NMR}$ Profiling and Carbon Isotope Discrimination as Tools for the Comparative Assessment of Walnut (Juglans regia L.) Cultivars with Various Geographical and Genetic Origins-A Preliminary Study. Molecules 2019, 24, 1378. [CrossRef]

Publisher's Note: MDPI stays neutral with regard to jurisdictional claims in published maps and institutional affiliations.

(C) 2020 by the authors. Licensee MDPI, Basel, Switzerland. This article is an open access article distributed under the terms and conditions of the Creative Commons Attribution (CC BY) license (http://creativecommons.org/licenses/by/4.0/). 